\title{
A RADIOCARBON DATABASE FOR SCOTTISH ARCHAEOLOGICAL SAMPLES
}

\author{
P J Ashmore \\ Historic Scotland, Longmore House, Salisbury Place, Edinburgh EH9 1SH, Scotland. \\ Email: Patrick.Ashmore@scotland.gov.uk. \\ G T Cook • D D Harkness \\ Scottish Universities Environmental Research Centre, Scottish Enterprise Technology Park, East Kilbride G75 0QF, Scotland
}

\begin{abstract}
For the majority of dating laboratories and their respective user communities, the journal Radiocarbon is no longer regarded as the medium for primary publication of radiocarbon measurements. In compliance with editorial policy, the emphasis has long since moved towards the publication of research papers on technological enhancements and applications of ${ }^{14} \mathrm{C}$ as well as other cosmogenic isotopes and this has left a requirement for an alternative medium for the publication of date lists per se. In the late 1980s, an International Radiocarbon Data Base was proposed by Renee Kra (then the managing editor) but limitations in computer and communications technologies together with the inevitable financial implications meant that this timely concept could not be taken to completion. In the last year, we have taken advantage of the development of the worldwide web to compile a database of ${ }^{14} \mathrm{C}$ age measurements of a Scottish archaeological nature which can be found at the web address http://www.historic-scotland.gov.uk/.
\end{abstract}

\section{INTRODUCTION}

We are all well aware of the breadth of scientific disciplines in which radiocarbon dating has had a fundamental role in advancing knowledge. Indeed, the first paper to be published in the American Journal of Science, Radiocarbon Supplement-the forerunner to Radiocarbon (Olson and Broecker 1959), lists measurements within the fields of archaeology, oceanography, glacial geology, and limnology. At this time, the Supplement was to "serve henceforth as the medium for primary publication of all radiocarbon measurements, or at least of radiocarbon date lists" (Deevey and Flint 1959). And so, the journal Radiocarbon became established as the focus for the ${ }^{14} \mathrm{C}$ dating technique and its scientific community. Therefore, this community has been fortunate in that from the outset of the applied chronology, it has benefited from an internationally agreed format for the definition and publication of results policed via a dedicated journal.

For approximately the next two decades, the journal continued as a medium for datelist publications although, despite the fact that application of the ${ }^{14} \mathrm{C}$ technique had expanded enormously, the number of published measurements did not increase in parallel. It was becoming obvious that the journal could no longer fulfil its initial perceived role. There was also a gradual shift in emphasis towards the publication of applications and technological innovations and this shift in editorial policy is highlighted by the change in name to Radiocarbon, An International Journal of Cosmogenic Isotope Research, coincident with the movement of the editorial office to the University of Arizona in 1989 and a stated intention to expand the journal's scientific outlook.

In 1987, Renee Kra reported at the Archaeology and ${ }^{14} \mathrm{C}$ Conference in Groningen that less than $10 \%$ of known ${ }^{14} \mathrm{C}$ measurements were being published in the journal and that a new vehicle for the dissemination of results was required. This was the first workshop on the International Radiocarbon Data Base (IRDB) (Walker and Kra 1988), a project that Renee pursued vigorously over the next few years (Kra 1988, 1989) to the stage where pilot projects were set up. Unfortunately, the technology of the day, which was very limited by current standards, was such that there were significant cost implications and the IRDB could not be carried through to completion. Nevertheless, the way ahead was demonstrated and the quantum leaps in technology that have occurred during the last decade make the development and worldwide dissemination of database entries a technologically 
trivial task. We would encourage other laboratories and/or appropriate consortium groups to consider this option if they have not already done so.

The date list described here is available at the web address http://www.historic-scotland.gov.uk/, and comprises the age measurements of a Scottish archaeological nature commissioned by Historic Scotland, together with others that have been identified within the published scientific literature, to the end of May 1996.

\section{Content and Arrangement of the Database}

The tables and columns contained in the database are arranged as follows.

\begin{tabular}{|c|c|}
\hline Site name & The name of the site \\
\hline Reference & $\begin{array}{l}\text { The name of the submitter or a bibliographic reference. 'Forthcoming' means } \\
\text { the site has not yet been published. }\end{array}$ \\
\hline National grid ref. & A six or eight figure national grid reference \\
\hline Calibrated age & $\begin{array}{l}\text { The Adjusted Age BP converted into a calendar date range using the pro- } \\
\text { gramme OxCal } 2.81 \text { and the } 1998 \text { calibration curve. The figures quoted are for } \\
\text { a range within which there is a } 95 \% \text { chance that the true age lies. }\end{array}$ \\
\hline $\begin{array}{l}\text { Context, taphonomy, } \\
\text { and comments }\end{array}$ & $\begin{array}{l}\text { A mixture of comments from the original submission and from subsequent con- } \\
\text { sideration. As used here, taphonomy means 'how the datable material in the } \\
\text { sample used for dating got to where it was found on the archaeological site'. }\end{array}$ \\
\hline Material dated & A simple division into charcoal, shell, human bone etc. \\
\hline Lab code & $\begin{array}{l}\text { The unique code quoted by the laboratory. Each consists of a laboratory iden- } \\
\text { tifier and a number. For instance, GU-1000 means age number } 1000 \text { from GU } \\
\text { (Glasgow University, now housed at the Scottish Universities Environmental } \\
\text { Research Centre). }\end{array}$ \\
\hline Laboratory age BP & $\begin{array}{l}\text { The conventional (raw) radiocarbon 'age' and error (one sigma) as quoted by } \\
\text { the laboratory or primary publication. BP means before present where present } \\
\text { is } 1950 \mathrm{AD} \text {. }\end{array}$ \\
\hline Adjusted age BP & $\begin{array}{l}\text { Error terms have been adjusted as explained below. Marine shell ages have been } \\
\text { adjusted to correspond to terrestrial ages. }\end{array}$ \\
\hline$\delta^{13} \mathbf{C}$ & $\begin{array}{l}\text { Basic radiocarbon theory assumes that there is global uniformity in the natural } \\
{ }^{14} \mathrm{C} /{ }^{12} \mathrm{C} \text { ratio. This is valid for the well mixed atmosphere and the flora and } \\
\text { fauna that it supports provided an allowance is made for the extent to which iso- } \\
\text { topic fractionation occurs during the assimilation and metabolic fixation of at- } \\
\text { mospheric carbon dioxide. Although plants obtain their carbon from the } \\
\text { atmosphere, the actual }{ }^{14} \mathrm{C} \text { activity in them is lower by } 3-4 \% \text { (equivalent to an } \\
\text { apparent excess age of between } 240 \text { and } 320 \text { years). For each sample a } \delta^{13} \mathrm{C} \\
\text { value is determined. This represents the difference in parts per thousand }(\%) \\
\text { between the ratio of }{ }^{13} \mathrm{C} \text { to }{ }^{12} \mathrm{C} \text { in the sample to the ratio in a standard (creta- } \\
\text { ceous belemnite, Belemnita americana, from the Peedee formation in South } \\
\text { Carolina, known as PDB). The fractionation between }{ }^{14} \mathrm{C} \text { and }{ }^{12} \mathrm{C} \text { is assumed to } \\
\text { be twice that induced between }{ }^{13} \mathrm{C} \text { and }{ }^{12} \mathrm{C} \text {. A correction factor is determined } \\
\text { which normalises all activities to those of wood (with a } \delta^{13} \mathrm{C} \text { of }-25 \% \text { ). Typical } \\
\text { values for a range of sample types are as follows: }-21 \% \text { for human or animal } \\
\text { bone, }-25 \text { to - } 6 \% \% \text { for charcoal, }-28 \text { to }-29 \% \text { for peat and } 0 \% \text { for marine } \\
\text { shell. Because preparation of samples for measurement can sometimes induce } \\
\text { a further small fractionation effect, and the quoted } \delta^{13} \mathrm{C} \text { value includes the re- } \\
\text { sults of this fractionation, most of the } \delta^{13} \mathrm{C} \text { measurements quoted here are not } \\
\text { suitable for inclusion in stable isotope studies. }\end{array}$ \\
\hline
\end{tabular}

Some ${ }^{14} \mathrm{C}$ ages in the list have not, so far as we are aware, been published. They are marked "forthcoming". Many Scottish archaeological ${ }^{14} \mathrm{C}$ ages obtained in 1995 and subsequent years have been published in Discovery and Excavation in Scotland (Ashmore 1996, 1997, 1998; Sheridan 1997b). 
Understanding of the significance of these ages will be greatly improved once their archaeological contexts have been fully published. Thus 1995-1996 provides a sensible cut-off date, at present, for inclusion of ${ }^{14} \mathrm{C}$ ages in this list.

\section{An Overview of Radiocarbon Research in Scottish Archaeology}

The impact of ${ }^{14} \mathrm{C}$ dating on our understanding of the prehistory of Scotland has been dramatic. Around 1950, chronologies were based on typology and long distance connections with the Mediterranean. The methods used to date sites encouraged the seeking of long distance direct links in a way that is not now found acceptable. Charles Calder, in his discussion of the Staneydale Temple, referred explicitly to Maltese structures (Calder 1952), then supposed to belong to the Bronze Age. While Staneydale, by analogy with the ${ }^{14} \mathrm{C}$ dated house at Ness of Gruting, probably belongs around the end of the third millennium BC or the start of the second (Barcham 1980), the Maltese Temples are generally third millennium in date. There is no known social or cultural link between the Shetland sites of around $2000 \mathrm{cal}$ BC and the earlier Maltese sites. Thus, the lack of an objective dating system independent of superficial similarities between structures distorted interpretations.

Around 1950, chronologies had become as short as they were ever to be. The Neolithic of Britain was telescoped by one of the most knowledgeable and well-informed prehistorians of the time into the period after 2000 BC (Piggott 1954:Figure 64). Nor was he alone. For instance, when the prominent Scottish prehistorian, Sir W Lindsay Scott, reported Neolithic pottery from Eilean an Tighe, near the Sound of Harris, he described it as "not later than the mid-second millennium BC" (Scott 1953). Indeed, he ascribed the site to the second millennium BC. It would now be dated by analogy with other sites with similar pottery broadly to the latter part of the fourth millennium BC. In short, ${ }^{14} \mathrm{C}$ shifted the dates for the Scottish Neolithic back 2000 years and extended it three or four-fold, with all sorts of consequences for archaeological interpretation.

There seems to have been some suspicion of ${ }^{14} \mathrm{C}$ ages at first. For instance, one of the first archaeological age measurement for Scottish material (BM-441 $3514 \pm 120$ BP) from the British Museum (Barcham 1980), from a large cache of grain at Ness of Gruting referred to above, was long unreported. Yet viewed as a whole, the dates from the "heroic age" of ${ }^{14} \mathrm{C}$ dating were often approximately correct, at least if it is accepted that the errors were somewhat underestimated. Some archaeologists sent samples to several laboratories (Renfrew et al. 1976; Renfrew 1989) and their results still make sense today. Indeed the problems with ages obtained in the "heroic age" seem in retrospect to be due at least as much to poor sampling by archaeologists and in particular the submission of mixed samples (Ashmore 1999) than to faults in laboratories, perhaps with a small number of exceptions (Spriggs and Anderson 1993). That at least is the likeliest explanation for the problematic ages from some sites, such as the intriguing late Neolithic enclosure at Raigmore near Inverness (Simpson 1996:82-3). That said, some very curious results still provide puzzles for archaeologists. For example, markedly different ages from animal bones from one context at the Neolithic houses at Knap of Howar in Orkney of $5706 \pm 85$ and $4081 \pm 65$ BP (SRR-347 and SRR-452, respectively) (Ritchie 1983).

Since that time, many of the then-operational laboratories seem to have ceased to provide archaeological age measurements. These include Birm (Department of Geology, Birmingham University, England), HAR (Harwell), and NPL (National Physical Laboratory, Teddington, Middlesex). The few that remain in Britain and Ireland are at the forefront of research on calibration and the accuracy and precision of the dating process, together with peers in other countries. That said, and more generally, there is currently an acknowledged tension between the provision of measurements at a price which archaeologists can afford and quality assurance for the whole process of dating from sample 
pretreatment onward. The latter continues to be addressed by international inter-comparison studies in which SUERC and Glasgow University have played a leading part. It is essential that such studies be continued and strengthened.

Despite the constant improvements in laboratory techniques, dating technology always lags behind archaeological expectations. While analysis of the organic material in each archaeological and paleoenvironmental context is normally restricted to one or two measurements (for reasons of cost) and while precision to within a few ${ }^{14} \mathrm{C}$ decades is the best that can be afforded, many archaeological and paleoenvironmental questions cannot sensibly be asked, let alone answered. Some of the problems are fundamental, relating to the variable proportion of ${ }^{14} \mathrm{C}$ to stable carbon in the atmosphere during the past; others arise because the ages of the samples are often proxies for the age of the context or activity which gave rise to the context.

There are, however, problems perceived by archaeologists and paleoenvironmental specialists which can be tackled by simple education. The first of these is a legacy of "heroic age" measurements. These are embedded in archaeological literature and there is a tendency to quote them with unrealistically high confidence, i.e. low numerical error terms. Agreement is required on sensible correction factors for error terms on ages measured in the period before the early 1980s. That requirement has been partly addressed in the database of archaeological age measurements from Scotland contained at the web address quoted above and no doubt, its publication will stimulate useful discussion and further improvements. The second is an archaeological and statistical problem. To overcome the problems of residual, turbated, and intrusive material in a context like a pit or posthole, large numbers of age measurements for individual entities together with careful statistical analysis will be required. Bayesian techniques (Buck et al. 1996) or, perhaps with a greater prospect of testing competing hypotheses, the "likelihood" approaches advocated by Edwards (1992) should be applicable to modeling the age spectra of organic inclusions in archaeological deposits.

Publication of the compendium of Scottish archaeological age measurements will allow a much improved assessment of the basis for current chronological models. For example, there is a tantalizing possibility that the early Neolithic of Scotland can be "debundled", in the sense that structural and pottery types currently assumed to be roughly contemporary can be shown to be chronologically distinct. For instance, the true relationship between the introduction of farming and of chambered cairn construction is poorly documented. The earliest dates from Scottish chambered tombs are from bulk samples which for the most part relate neither to use nor construction but to activity on underlying old ground surfaces as at Port Charlotte (Harrington and Pierpoint 1980; RCAHMS 1984:502) and Camster (Masters 1997:133, 157) or, as at Monamore, are arguably either less precise than claimed or misinterpreted (MacKie 1966a, 1966b). Although an age from Tulloch of Assery B for animal bones on the floor of the tomb (Sharples 1986) may hint that the commonly accepted picture of construction and use of chambered tombs starting around $4000 \mathrm{BC}$, or at least significantly earlier than $3500 \mathrm{BC}$, is not far wrong, it may equally well be that chambered tombs were first built in Scotland at a significantly later date than the introduction of farming.

Analysis of the ${ }^{14} \mathrm{C}$ ages in the list will also probably help to generate new models. For instance, there is an intriguing hint in the distribution of ${ }^{14} \mathrm{C}$ ages that the use of cinerary urns and related domestic urns may neatly fill the period between primary use of late Neolithic ceremonial sites and their re-use in the later Bronze Age (Ashmore, forthcoming). In other words, the ceremonial sites may have fallen out of memory for over half a millennium before they became one of the preferred sites for burial. It will also help the testing of competing ideas. For instance, the list makes it immediately apparent that more secure dating of the Stones of Stenness (Ritchie 1976) and Knap of 
Howar (Ritchie 1983) has the potential to help to resolve current controversies over social models for early Orkney.

More generally, the opportunities for improvement provided by reduction in the size of samples required, and improvements in precision, are highly significant. Publication of Scottish archaeological ages in a form that allows an overview means that gaps in the dating of structural and pottery types can be better identified and addressed. Taking these factors together, the future for modeling of Scotland's heritage is indeed rosy.

Almost all of the age measurements commissioned by Historic Scotland before the end of May 1995 were carried out by the two Scottish laboratories whose laboratory codes have the prefixes GU and SRR. The original Scottish Universities Research and Reactor Centre (SURRC) Radiocarbon Dating Laboratory (SRR laboratory code) was established by Doug Harkness in East Kilbride. The laboratory produced many of the early Scottish archaeological age measurements, however, in 1974, it moved to an adjacent building on site when its remit changed and it became a central facility for the UK's Natural Environment Research Council (NERC), providing dating support in the environmental sciences. The Glasgow University Laboratory (GU laboratory code), which was run by Mike Stenhouse and subsequently Gordon Cook, continued to carry out Scottish archaeological work funded by the SDD Ancient Monuments Division (subsequently Historic Scotland) as well as its own in-house research. In 1986 the Glasgow University Radiocarbon Laboratory was relocated at SURRC (now SUERC) under the direction of Gordon Cook. Thus, the two Scottish ${ }^{14} \mathrm{C}$ laboratories were then, and are still, in adjacent buildings; one carrying out dating support for NERC and the other having a largely archaeological remit, both carrying out their own in-house research. This proximity has been mutually beneficial and the two laboratories have secured joint funding for several research projects. It is therefore a logical extension of this collaboration that the laboratories should jointly publish all of their archaeological measurements in a database format in conjunction with Historic Scotland.

\section{Quoted Errors and User Confidence}

The concept of error terms associated with age measurements has changed over the past two decades. The accuracy of ${ }^{14} \mathrm{C}$ dating has increased considerably, and several international studies initiated by Dr Marian Scott and the Scottish laboratories (International Study Group 1982; Scott et al. 1990, 1997; Gulliksen and Scott 1995) and others (Otlet et al. 1980; Rozanski et al. 1992) have encouraged ${ }^{14} \mathrm{C}$ dating laboratories worldwide to ensure that the results they produce are accurate and that their quoted errors accurately reflect their true analytical confidence. The conclusion of the International Study Group (1982) was that, while the results from the laboratories included in the study were in general agreement, they revealed the existence of systematic bias and unexplained variability. As a general guideline for users of ${ }^{14} \mathrm{C}$ dates, it was advised that quoted errors, particularly those derived solely on the basis of counting statistics, should be multiplied by a factor of between 2 and 3. Dr M Stenhouse of the Glasgow University Laboratory recommended in 1982, on the basis of his participation in the study, that all the errors he had quoted for laboratory numbers up to GU-1500 should be multiplied by 1.4 and that these age measurements should be subject to a minimum error of $\pm 110 \mathrm{yr}$ after multiplication (MJ Stenhouse, personal communication.). Intercalibration studies confirm that since the mid 1980s, the quoted errors of the GU laboratory which has provided the majority of archaeological ages have in general been representative of the true errors and that there has been no significant bias in its results. The following table indicates the performance of the Glasgow University and NERC Radiocarbon Dating Laboratories in the Third International 
Radiocarbon Intercomparison (TIRI). The table demonstrates that both sets of results are, as a group, very much in line with the consensus results.

Table 1 TIRI performance of the Glasgow University and NERC ${ }^{14} \mathrm{C}$ dating laboratories

\begin{tabular}{cccc}
\hline $\begin{array}{c}\text { TIRI } \\
\text { sample code }\end{array}$ & $\begin{array}{c}\text { TIRI consensus result } \\
\left(\mathrm{pMC}^{\mathrm{a}} \text { or age } \mathrm{BP} \pm 1 \sigma\right)\end{array}$ & $\begin{array}{c}\text { SURRC result } \\
(\mathrm{pMC} \text { or age } \mathrm{BP} \pm 1 \sigma)\end{array}$ & $\begin{array}{c}\text { NERC result } \\
(\mathrm{pMC} \text { or age } \mathrm{BP} \pm 1 \sigma)\end{array}$ \\
\hline $\mathrm{A}$ & $116.35 \pm 0.0084 \mathrm{pMC}$ & $116.32 \pm 0.58 \mathrm{pMC}$ & $115.42 \pm 0.60 \mathrm{pMC}$ \\
$\mathrm{B}$ & $4503 \pm 6 \mathrm{BP}$ & $4540 \pm 50 \mathrm{BP}$ & $4,500 \pm 45 \mathrm{BP}$ \\
$\mathrm{C}$ & $129.7 \pm 0.08 \mathrm{pMC}$ & $129.34 \pm 0.54 \mathrm{pMC}$ & $130.21 \pm 0.64 \mathrm{pMC}$ \\
$\mathrm{D}$ & $3810 \pm 7 \mathrm{BP}$ & $3830 \pm 50 \mathrm{BP}$ & $3780 \pm 45 \mathrm{BP}$ \\
$\mathrm{E}$ & $11,129 \pm 12 \mathrm{BP}$ & $11,270 \pm 70 \mathrm{BP}$ & $11,090 \pm 50 \mathrm{BP}$ \\
$\mathrm{F}$ & $46,750 \pm 208 \mathrm{BP}$ & $>43,000 \mathrm{BP}$ & $>62,000 \mathrm{BP}$ \\
$\mathrm{G}$ & $39,794 \pm 620 \mathrm{BP}$ & $40,300 \pm 2520 \mathrm{BP}$ & $>51,700 \mathrm{BP}$ \\
$\mathrm{H}$ & $11,152 \pm 23 \mathrm{BP}$ & $11,150 \pm 70 \mathrm{BP}$ & $11,180 \pm 40 \mathrm{BP}$ \\
$\mathrm{I}$ & $11,060 \pm 17 \mathrm{BP}$ & $11,040 \pm 60 \mathrm{BP}$ & $11,135 \pm 40 \mathrm{BP}$ \\
$\mathrm{J}$ & $1605 \pm 8 \mathrm{BP}$ & $1590 \pm 50 \mathrm{BP}$ & $1635 \pm 40 \mathrm{BP}$ \\
$\mathrm{K}$ & $18,155 \pm 34 \mathrm{BP}$ & $17,900 \pm 140 \mathrm{BP}$ & $18,135 \pm 100 \mathrm{BP}$ \\
\hline
\end{tabular}

${ }^{\mathrm{a}} \mathrm{pMC}=$ percent modern carbon

It is well known that in the past, some laboratories often quoted mainly or only the "counting errors" associated with the sample, background and modern reference standard activities. They did not include some or all of the several other possible sources of error in their measurements. Some of the additional sources of error, associated with these early assays, may have been systematic while others may have been random, but larger than allowed for by the laboratory in quoting the error on the measurement. It seems very likely indeed that the errors attached to the ${ }^{14} \mathrm{C}$ ages produced by many laboratories (but not all) up to the early to mid 1980s should be increased significantly if they are to be comparable with errors quoted today. Although it may be invidious to single out one laboratory, comparison of $\mathrm{GaK}$ ages for sites in the Pacific with those obtained by other laboratories has suggested that the errors attached to GaK dates are very considerably higher than those quoted by the laboratory (Spriggs and Anderson 1993). In the described database, some more realistic errors are indicated in the next-to-last column (although it must again be emphasized that these are open to challenge, because there is no scientific basis for attaching any particular correction factor to any particular age measurement in this list (apart from those GU ages covered by Dr Stenhouse's advice) and because there is no widespread agreement on how to correct early error assessment. In general, the error terms attached to more recent ${ }^{14} \mathrm{C}$ age measurements are reliable. The calibrated ages are based on these more realistic errors because it seems most sensible to apply the precautionary principle: better to be occasionally overcautious than to run the risk of spurious precision.

The ${ }^{14} \mathrm{C}$ ages were calibrated using OxCal 2.18 (Bronk Ramsey 1995) and the 1998 calibration curve (Stuiver et al. 1998). Dates marked forthcoming should not be quoted without the consent of the person named in the database. 


\section{REFERENCES}

Ashmore PJ. 1996. A list of Historic Scotland archaeological radiocarbon dates. In: Turner R, editor. Discovery and excavation in Scotland. Edinburgh: Council for Scottish Archaeology Publishers. p 136-42.

Ashmore PJ. 1997. A list of Historic Scotland archaeological radiocarbon dates. In: Turner R, editor. Discovery and excavation in Scotland. Edinburgh: Council for Scottish Archaeology Publishers. p 112-7.

Ashmore PJ. 1998. A list of Historic Scotland archaeological radiocarbon dates. In: Turner R, editor. Discovery and excavation in Scotland. Edinburgh: Council for Scottish Archaeology Publishers. p 125-8.

Ashmore PJ. 1999. Radiocarbon dating: avoiding errors in dating by avoiding mixed samples. Antiquity 73 : 124-30.

Ashmore PJ. Settlement in the second millennium BC in Scotland. In: Bruck J, editor. Landscape and settlement in Bronze Age Britain. Oxford: Oxbow Publishers. Forthcoming.

Barcham RC. 1980. A lost radiocarbon date for Shetland Islands. Proceedings of the Society of Antiquaries of Scotland 110:502-6.

Bronk Ramsey C. 1995. Radiocarbon calibration and analysis of stratigraphy: the Oxcal program. Radiocarbon 37(2):425-30.

Buck CE, Cavanagh WG, Litton CD. 1996. The Bayesian approach to interpreting archaeological data. Chichester: Wiley Publishers.

Calder CST. 1952. Report on the Excavation of a Neolithic Temple at Staneydale in the Parish of Sandsting, Shetland. Proceedings of the Society of Antiquaries of Scotland 85:185-205.

Edwards AWF. 1992. Likelihood: expanded edition. Baltimore and London: The John Hopkins University Press.

Flint RF, Deevey ES Jr. 1959. American Journal of Science Radiocarbon Supplement 1: preface.

Gulliksen S, Scott EM. 1995. TIRI report. Radiocarbon 37(2):820-1.

Harrington P, Pierpoint S. 1980. Port Charlotte chambered cairn, Islay: an interim note. Glasgow Archaeological Journal 7:113-5.

International Study Group. 1982. An inter-laboratory comparison of radiocarbon measurements in tree rings. Nature 198:619-23.

Kra R. 1988. The first American Workshop on the international radiocarbon data base. Radiocarbon 30(2): 259-60.

Kra R. 1989. The international radiocarbon data base: a progress report. Radiocarbon 31(3):1067-74.

MacKie EW. 1963-1964. New excavations on the Monamore Neolithic chambered cairn, Isle of Arran. Proceedings of the Society of Antiquaries of Scotland 97:1-34.

MacKie EW. 1964. The radiocarbon dates from a Clyde-Solway chambered cairn. Antiquity 38: 52-4.
Masters L. 1997. The excavation and restoration of the Camster long chambered cairn, Caithness, Highland. Proceedings of the Society of Antiquaries of Scotland 127:123-83.

Olson EA, Broecker WS. 1959. Lamont natural radiocarbon measurements V. American Journal of Science Radiocarbon Supplement 1:1-28.

Otlet RL, Walker AJ, Hewson AD, Burleigh R. $1980 .{ }^{14} \mathrm{C}$ interlaboratory comparison in the UK: Experiment design, preparation and preliminary results. Radiocarbon 22(3):936-46.

Piggott S. 1954. The Neolithic cultures of the British Isles. Cambridge: Cambridge University Press.

Royal Commission on the Ancient and Historical Monuments of Scotland. 1984. Argyll: an Inventory of the Monuments, 5: Islay, Jura, Colonsay and Oronsay. Edinburgh: HMSO Publishers.

Renfrew AC. 1989. Investigations in Orkney. Rep. Research Comm. Soc. Ants. London. London.

Renfrew AC, Harkness DD, Switsur VR. 1976. Quanterness, radiocarbon and the Orkney cairns. Antiquity 50: 194-204.

Ritchie A. 1983. Excavation of a Neolithic farmstead at Knap of Howar, Papa Westray, Orkney. Proceedings of the Society of Antiquaries of Scotland 113:40-121.

Ritchie JNG. 1976. The Stones of Stenness, Orkney. Proceedings of the Society of Antiquaries of Scotland 107: $1-60$.

Rozanski K, Stichler W, Gonfiantini R, Scott EM, Beukens RP, Kromer B, Van der Plicht J. 1992. The IAEA ${ }^{14} \mathrm{C}$ intercomparison exercise, 1990. Radiocarbon 34(3):506-19.

Scott EM, Aitchison TC, Harkness DD, Cook GT, Baxter MS. 1990. An overview of all three stages of the international radiocarbon intercomparison. Radiocarbon 32(3):309-19.

Scott EM, Harkness DD, Cook GT. 1997. Analytical protocol and quality assurance for ${ }^{14} \mathrm{C}$ analyses: proposal for a further intercomparison. Radiocarbon 39(3): 347-51.

Scott Sir WL. 1953. Eilean an Tighe: a pottery workshop of the second millennium BC. Proceedings of the Society of Antiquaries of Scotland 85:1-37.

Sharples NM. 1986. Radiocarbon dates from three chambered tombs at Loch Calder, Caithness. Scottish Archaeological Review 4(1):2-10.

Sheridan JA. 1997. The National Museums of Scotland archaeological radiocarbon dating programme: dates obtained during 1997. In: Turner R, editor. Discovery and excavation in Scotland. Edinburgh: Council for Scottish Archaeology Publishers. p 117.

Simpson DDA. 1996. Excavation of a kerbed funerary monument at Stoneyfield, Raigmore, Inverness, Highland, 1972-3. Proceedings of the Society of Antiquaries of Scotland 126:53-86.

Spriggs M, Anderson A. 1993. Late colonisation of East 
Polynesia. Antiquity 67:200-17.

Stuiver M, Reimer PJ, Bard E, Beck JW, Burr GS,

Hughen KA, Kromer B, McCormac G, Van der Plicht J, Spurk M. 1998 INTCAL98 radiocarbon age calibration, 24,000-0 cal BP. Radiocarbon 40(3):1041-84.
Walker AJ, Kra R. 1988. Report on the International Radiocarbon Data Base (IRDB) Workshop, Archaeology and ${ }^{14} \mathrm{C}$ Conference, Groningen, The Netherlands. $R a$ diocarbon 30(2):255-8. 